\title{
The National Herbarium of New South Wales - One Hundred Years
}

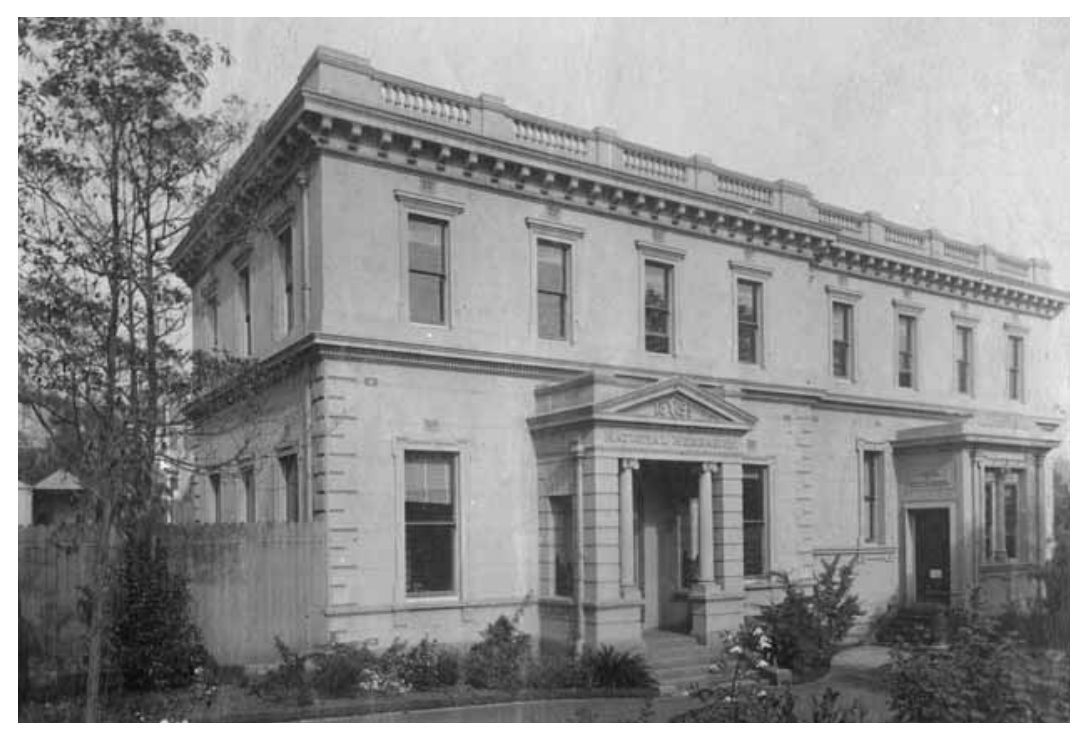

The first home of the National Herbarium of New South Wales, now known as the R.H. Anderson Building. The portico on the right leads to the original Museum and Lecture Hall, a single room constructed in 1878 and incorporated into the twostorey building that was opened in 1901. The entrance on the left bears the title 'National Herbarium' and '1899', the date of construction of that part of the building, and leads to the J.H. Maiden Lecture Theatre.

This issue of Telopea commemorates the centenary on 8 March 2001 of the first home of the National Herbarium of New South Wales, and also Joseph Henry Maiden (Director of the Botanic Gardens 1896-1924) who founded the Herbarium and first established its scientific reputation.

Sydney's Royal Botanic Gardens has a proud status as Australia's oldest continuing scientific institution, persisting at its Farm Cove site and with a scientist (or 'botanical soldier' in the case of its first Superintendent, Charles Fraser) at its helm from its earliest days. In 1916 the centenary of its foundation was celebrated, taking the completion of the encircling road in 1816 as marking its identity and foundation (Gilbert 1986). Initially the site was envisaged as an entrepot, from where samples of the 'vegetable resources' of the new colony would be shipped to Britain, the Mother Country, and where plants needed by the colonists could be established and distributed. In keeping with such close links to Britain, the young settlement was not seen as a place for permanent scientific collections - these were sent to Europe for safe keeping and expert study. So the Herbarium's foundation, forty years later than its counterpart in Melbourne, is dated from when Joseph Henry Maiden took up duty as Director in 1896.

Maiden had come from England as a young man but had no doubt that Australia was a place for enduring scientific organisations and specimen collections. His early years in Sydney had been as the first Curator of the Technological Museum, forerunner of today's Powerhouse Museum. As at the Museum, his priority on appointment to the 
Gardens was to seek support and funding from the New South Wales Government for construction of a substantial building for rapidly increasing collections and scientific and office staff. His outstanding vision, energy, persistence and powers of persuasion led to success in both cases, and the herbarium building was opened on 8 March 1901, within five years of his appointment at the Gardens. The early years of the Herbarium are the story of that dominant figure, Maiden, whose achievements encompassed also important developments in the Gardens and elsewhere, as well as many and varied scientific publications, contributions to scientific societies, community projects and adult education (Gilbert 2001).

The new two-storey building incorporated an existing Museum room and Lecture Hall built in 1878, during Charles Moore's long directorship (1848-96). Most of the space on both levels held wooden racks for cardboard specimen boxes, interspersed with working areas for the few staff. The Lecture Hall and Museum displaying the economic uses of plants remained in regular use, continuing to give evidence of the importance Maiden also placed on education and outreach to the community.

On arrival at the Gardens, Maiden had found a pitifully deficient library and specimens of only 'a thousand or two named species', but soon the library was growing and the spacious specimen rooms were filling, as Maiden and his staff collected enthusiastically, mostly wherever they could reach by train and foot, rarely by horseback. Botanical assistant Ernst Betche, collector John Boorman, and horticultural managers William Forsyth and Julius Camfield all contributed their specimen collections. Along with vascular plants, there were fungi, lichens, algae, bryophytes, plant products and wood specimens, with small sections devoted to teratological examples and plant galls. Specimen exchanges were established with leading herbaria worldwide and many of the specimens received for identification from all parts of New South Wales were retained for the collection. Part of the herbarium that Maiden had assembled during his 15 years at the Technological Museum was transferred; the remainder was received much later, in the 1980s. During a visit in 1900 by Maiden to the British Museum (Natural History) in London, the case was strongly and successfully made for sending to Sydney duplicates of the Banks and Solander collections from Cook's voyage in 1770; more than 800 duplicates were received. The efforts of knowledgeable amateur collectors were encouraged and some significant collections purchased. The emphasis was on developing comprehensive local and world representation of taxa; since resources were limited the specimens remained largely unmounted.

The botanical output of the Herbarium was overwhelmingly that of Maiden, who worked individually on Eucalyptus, Acacia, the Forest Flora of New South Wales and on plants of economic importance, but also published with his colleagues Betche, Blakely and Cambage on a wide range of groups. Alone or with colleagues he was responsible for a vast and varied range of scientific publications and other articles, including the description of more than 300 new species. Excellent illustrations by Margaret Flockton contributed to many of the publications.

Almost single-handedly, Maiden had built a scientific and international reputation for the Herbarium but this was not maintained in the decades following his retirement in 1924. With the backdrop of economic depression, resources were grossly inadequate and leaders lacked vision for the scientific or community roles of the organisation. Added to this was a worldwide reduction in the scientific standing of taxonomy. The administrative control of Gardens and Herbarium was divided, with a Gardens Curator and a Herbarium Curator (or later Chief Botanist), instead of a unitary position of Director. All had been within the New South Wales Department of Agriculture since 1880, but for years the Herbarium was administratively separated as a Branch of the Science Services Division of that Department. Moreover, these decades 
predated the wider community awareness and concern for environmental and biodiversity conservation that has helped botanic gardens worldwide to redefine their aims, and also the resurgent interest in phylogeny, driven by cladistics and molecular genetics, that has revivified biological systematics.

The upturn was slow but, once started, made steady progress. From the late 1930's R.H. (Bob) Anderson (Herbarium Curator and subsequently Chief Botanist, 1936-64) was able to appoint graduates with research experience who were becoming available to fill new botanical positions. Published scientific output increased greatly after 1939 when the series Contributions from the New South Wales National Herbarium was initiated, forerunner of today's Telopea. The Gardens and Herbarium were administratively re-united and ecological work introduced under Director Knowles Mair (1964-70), while educational programs were initiated by Director John Beard (1970-72). A new herbarium building and the many new opportunities it brought, as well as expansion of the scientific programs were notable during L.A.S. (Lawrie) Johnson's leadership (1972-1985, Briggs 2001) while improvement of the horticultural lands and their landscape features characterised Carrick Chambers' directorship (1986-1996), along with further expansion of herbarium and office space in the new building. The development of the satellite gardens at Mount Tomah and Mount Annan, publication of a four-volume Flora of New South Wales (Harden 1990-93, 2000, $\&$ in press), establishment of electronic data recording and DNA research were developments that energised the whole organisation and were spread -to varying extents- over several directorships during the last three decades of the century. Recent emphasis with Director Frank Howarth (1996-present), across both the Herbarium and Gardens, is on biodiversity conservation, communicating information by electronic media and forging closer links with other government agencies and universities.

From the 1940s into the 1960s, the Herbarium had been headed by an experienced Botanist informally although effectively guiding less knowledgeable botanists, with management a relatively infrequent and unwelcome interruption into botanical work, as in Joyce Vickery's time (1936-68). Acknowledgment that the Herbarium and scientific programs needed to be managed as an entity within the organisation came with Lawrie Johnson's appointment as Deputy Chief Botanist (1968-72); the position was subsequently retitled Senior Assistant Director (Scientific) while held by myself (1972-97). Now there is a Director Plant Sciences Branch, Tim Entwisle, assisted by a management team, with the Herbarium and systematics forming the Plant Diversity Section. The scope of research has widened geographically and also into new fields, especially in algae and bryophytes, and now the systematists have ecologists, plant pathologists and horticultural researchers among their colleagues, but economic botany (apart from the occurrence of weeds) and the development of general fungal collections are not current priorities. International links have been greatly strengthened and cooperation among botanists and botanical institutions within Australia fostered by the Council of Heads of Australian Herbaria, the Australian Systematic Botany Society and other scientific associations.

The Director's office has continued to be where Maiden established it, except for a short period when Director John Beard had his office in the Cunningham Building. The Herbarium and its staff moved in 1982 from Maiden's building to a long sought and newly constructed adjacent building, providing the desperately overcrowded collections and library with space for some years of growth, as well as vastly improved working conditions and space for laboratories. Research in molecular systematics, a database of specimen data and a volunteers' program to mount the specimens could then be initiated. The space vacated was quickly put to use as a classroom and offices for education programs, lecture theatre, accommodation for Corporate Services staff, Visitor Centre and Gardens' Shop. The Visitor Centre functioned there until 2000 when 
it was transferred to a building in a more central location in the Gardens. Buildings were commemoratively named after the great botanist Robert Brown (the new Herbarium building) and two former directors: Robert Anderson (the old Herbarium) and Allan Cunningham (the director's residence, built in 1874, in Moore's time, now providing offices for staff). Maiden's name graces the lecture theatre in the Anderson Building, so essential to community activities, including those of the Friends of the Gardens, and to education.

In many respects the National Herbarium of New South Wales and also the Royal Botanic Gardens Sydney have come full circle, confident of their status in science, internationally recognised and outgoing in serving their community, as they were in the time of J.H. Maiden.

\section{Acknowledgment}

This brief account has depended greatly on the research and publications of Dr Lionel Gilbert OAM, Honorary Research Associate of the Royal Botanic Gardens Sydney, and especially on his works cited below.

\section{References}

Briggs, B.G. (2001) Lawrence Alexander Sidney Johnson 1926-1997. Hist. Rec. Austral. Sci. 13 (4) (in press).

Gilbert, L. (1986) The Royal Botanic Gardens, Sydney: a History, 1916-1985. (Oxford University Press: Melbourne).

Gilbert, L. (2001) The Little Giant: the Life and Works of Joseph Henry Maiden. (Kardoorair Press: Armidale).

Harden, G.J. (Ed.) (1990-93) Flora of New South Wales. Vols 1-4 and revised editions vol.1 (2000), vol. 2 (in press) (New South Wales University Press: Sydney).

Barbara G. Briggs

Royal Botanic Gardens Sydney

Mrs Macquaries Road, Sydney NSW 2000, Australia

e-mail barbara.briggs@rbgsyd.nsw.gov.au 